\title{
Region Expansion through Base Sector Expansion: An Evidence from Location Quotient Approach
}

\author{
Murtala $^{1}$, Chalirafi $^{2}$, Teuku Roli Ilhamsyah Putra ${ }^{3}$, Eddy Gunawan $^{4}$, Amri $^{4}$, Irham Iskandar $^{5}$ \\ \{murtala@gmail.com ${ }^{1}$ \} \\ ${ }^{1}$ Department of Economic Development, Faculty of Economics and Business, Universitas \\ Malikussaleh, Lhokseumawe, Indonesia \\ ${ }^{2}$ Department of Management, Faculty of Economics and Business, Universitas Malikussaleh, \\ Lhokseumawe, Indonesia \\ ${ }^{3}$ Department of Management, Faculty of Economics and Business, Universitas Syiah Kuala, Banda \\ Aceh, Indonesia \\ ${ }^{4}$ Department of Economic Development, Faculty of Economics and Business, Universitas Syiah Kuala, \\ Banda Aceh, Indonesia \\ ${ }^{5}$ Regional Development Planning Board, Aceh Province, Indonesia
}

\begin{abstract}
The objective of this research is to acknowledge which sectors can become a strategy in region expansion through base sector expension in Aceh Province. Research model used in this research isLocation Quotient (LQ) model and Klassen Typology. Research result by using Klassen Typology shows that during 2003-2005 there was one district in Aceh province that can be categorized as high growth and high income region.There was one district in Aceh province that can be categorized as high income but low growth region. There were 10 (ten) regencies in Aceh province that can be categorized as high growth but low income regions and eleven regencies in Aceh province that can be categorized as low growth and low income regions.In 2006-2008 there were 10 regencies/municipalities in Aceh province that can be categorized ashigh growth and high income regions and 4 (four) regencies in Aceh province that can be categorized as low growth and low income regions. In 2006-2008 there were thirteen regencies/municipalities in Aceh province that can be categorized ashigh growth and high income regions and ten regencies in Aceh province that can be categorized as low growth and low income regions.
\end{abstract}

Keywords: Region Expansion through Base Sector Expansion

\section{Introduction}

In the reality economic growth in Indonesia is not relevant to labor structure changing. This means that the rate of sectoral economic shift is relatively faster than the rate of labor shift, so that the turning point for economic activities is exceedingly reached than labor turning point [1]. The economic growth in Indonesia is not in line with labor structure changing in current reality. Region expansion is an effort to develop an area in order to increase people's incomes so that the welfare can be attained in that region. Region expansion is well known as development. Region development is interpreted as an objective from either all vision or mission from region or area authorities, either in development or expansion which 
can overcome all problems. There are many ways that can be taken in order to make a region develops, one of them is by managing resources and forming a partnership between local government and private sectors in order to create new working opportunities and to stimulate economic development activities (economic growth) in that region [2]. Aceh province experiences increasing growth from year to year. Up to 2012 Aceh economic growth was 5.02 percent (oil and gas growth rate), with constant price of GRDP as much as 34,779,700.000 rupiah. The above growth increases by 4.78 percent from the prior year which was as much as $33,118,170,000,000$ rupiah [3].

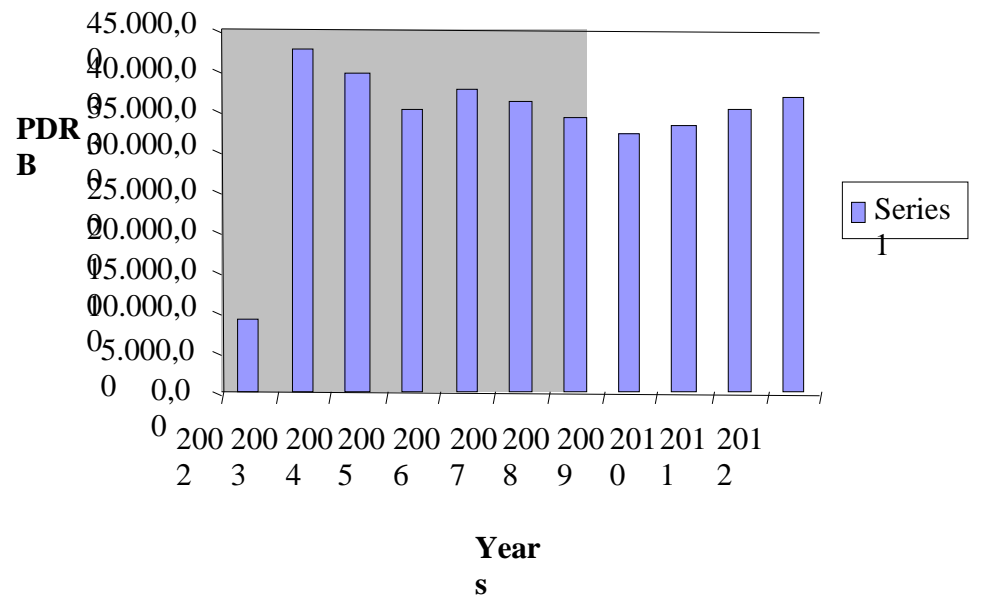

Figure 1. Aceh GRDP in 2002 - 2012 (in Billion Rupiah) Source: BPS, Aceh In Numbers 2012

Agriculture sector was the sector that can survive during crisis and gave the highest contribution to GRDP in Aceh due to the availability of potential lands in Aceh, even the widest land according to its use is the forest (bushes, shrubs) as much as 2,291,080 ha from Aceh Province Aceh width which is 5,677.081 ha [3]. For region expansion, Aceh government should choose one prominent sector in Aceh in order to reach region growth. Region expansion through base sector can be implemented if the government and the societies allocate resources in Aceh province well and produce well product. The government can intervene on production cost while the societies can manage the resource to produce a product. The product can have greater added value than the raw materials. This is done in order to increase growth, people's incomes for reaching even welfare. Figure 1 describes Aceh GRDP from 2002 to 2012 which fluctuated a lot, the highest GRDP was in 2003 as much as 42,239.31 billion rupiah, then kept on fluctuating until 2012 Aceh GRDP was as much as Rp 36,599.73 billon.

\section{Research Methods}

\subsection{Region Expansion}

Region is an area that has same characteristic either by natural or human that has clear administrative limits based on permanent rule in the valid law. Region expansion presents region expansion concept in Indonesia which has several base theories [4]. The first one is 
Walter Isard as the pioneer of region science which examine cause and effect relationship from major factors of region forming which are physical, social economic and culture factors.

The second one is Hirchmann (1950s) who presented polarization effect and trickling down effect with the argumentation that a region is not formed at the same time (unbalanced development).The third one is Myrdal (1950s) with the theory that explain the relationship between backwash effect and spreadwash effect. The fourth one is Freedmann (1960s) who emphasized more on hierarchy forming in order to ease the expansion of development system which known as growth centre theory. The fifth one is Douglas (1970s) who introduced ruralurban linkages in region expansion. Nodal region or polarization region functionally have dependency between centre governement and its back region while planning region is made by its closeness, logically interrelated and is a unit of economic decision making [5]. Region expansion according to [6] is a series of efforts to create integrity in utilizing various resources, to bind and to balance national expansion and national region, to increase the harmony among areas, to have integrity among expension sectors through spatial planning process in order to achieve the objective of sustainable expansion within Republic of Indonesia.

\subsection{Region Expansion Theory}

There are many factors that can infuence region expansion, the region expansion process is based on the way how to apply methods so that the region can develop. The region expansion methods are as follows:

\section{a. Richardson export base theory}

This theory is initially developed by Tiebout, it describes that a region can grow and develop based on its export base activities. This theory devides its activities or kind of works in a region as basic work and service work, in order to avoid misunderstanding, service work is mentioned as non basic work. Base activities is exogenous activities which means it is not related to region economic internal condition and its function is to stimulate the growth of other works [7].

\section{b. Neo Classic Theory}

According to [8], this neo classic theory descibes that a region or country will develop based on phases. The mechanism from these phases is the important aspect in the process of expansion and development of a region. Harrod-Domar theory is based on the following assumptions:

a. Close Economic

b. Saving desire (MPS $=$ s) is constant

c. Production process has constant coeficient (constant return to scale) and

d. Labor growth rate (n) is constant and equal to population growth rate.

\subsection{GRDP Definition}

GRDP can be defined as number of added value that is gained by all units of work or number of all goods and services value by all economic units in an region.GRDP on valid price describes goods and services added value which is calculated by price while GRDP on constant price shows goods and service added value which is calculated by prices in certain year based on calculation base [9], [10] states that Regional Gross Domestic Product is value from all goods and services production which are gained by various economic activities in a region, in a certain period, usually every year. GRDP is an important indicator to acknowledge the implemented region development success rate and it is useful to determine development direction in the future. In the reality GRDP describes a region economic activities rate, which are implemented by the societies, private sector or government in a certain period, which 
cover all production output that are created by a region. So indirectly GRDP can be utilized as an indicator in appraising region economic development activities results as a whole.The purposes of GRDP are:

1. To show the capacity of economic resources which are produced by a region or province. The higher GRDP value shows the higher economic resource capacity.

2. To show income that can be benefited by all population/societies in a region or province.

3. utilized to show economi growth rate as a whole from year to year.

4. Sector GRDP shows the amount of economic structure and the role of economic sector in a region, economic sectors which have huge role show a region economic base.

5. GRDP based on its utilization shows how goods and services products are used for consumption, investment, and are traded to outer parties.

6. GRDP distribution based on its utilization shows the institutional role based on goods and services produced by economic sector.

7. GRDP based on its constant price utilization is useful for measuring consumption growth rate, investment and foreign trade or trade inter-island or province.

8. GRDP and PRDB per capita based on valid price shows GRDP value and GRDP per capita or per person.

9. GRDP and PRDB per capita based on constant price is useful to acknowledge real economic per capita.

To acknowledge which sectors can be used as strategy in region expansion through base sector expansion in Aceh, we can carry out LQ (Location Quotient) approach.

LQ equation [7] is as follows :

$$
L Q=\frac{v i / v t}{V i / V t}
$$

Which

$\mathrm{LQ}=$ Location Quotient

$\mathrm{vi}=\mathrm{i}$ sector output in analyzed region (Aceh Province)

$\mathrm{vt}=$ total output in analyzed region (Aceh Province)

$\mathrm{Vi}=\mathrm{i}$ sector output in regional (Indonesia)

$\mathrm{Vt}=$ total regional output (Indonesia)

The criteria are:

1. If $\mathrm{LQ}>1$ shows that the sector is catagorized as the major sector in a region.

2. If $L Q<1$ shows that the sector is not categorized as major sector in a region.

3. If $L Q=1$ shows the self-supporting major sector in a region.

In other side of this research, Klassen Typology analysis tool is also used to acknowlegde the figure on region pattern and classification which are based on two major indicators, which are region economic growth and GRDP per capita. By determining average economic growth as vertical axis and average GRDP per capita as horozontal axis, the analyzed regions can be classified into four, which are:

1. High growth and high income region, the region that have economic growth rate and GRDP per capita higher compared to Aceh province average.

2. High income but low growth region, the region that have GRDP per capita higher but lower economic growth compared to Aceh province average.

3. High growth but low income region, the region that have higher economic growth but lower GRDP per capita compared to Aceh province average

4. Low growth and low income region, the region that have lower economic growth and GRDP per capita compared to Aceh province average 
Table 1. Tipologi Klassen

\begin{tabular}{|c|c|c|}
\hline $\mathbf{R}^{\mathbf{P}^{\prime}}$ & $\overline{Y_{i j}<Y_{j}}$ & $\overline{Y_{i j}}>Y_{j}$ \\
\hline $\mathbf{R}_{\mathbf{i}}$ & Quadrant III & Quadrant I \\
\hline $\mathbf{j}>\mathbf{R}_{\mathbf{j}}$ & High growth but low income region & $\begin{array}{l}\text { High growth and high income } \\
\text { region }\end{array}$ \\
\hline$\underset{j}{\mathbf{j}}<\mathbf{R}_{\mathbf{j}}$ & $\begin{array}{l}\text { Quadrant IV } \\
\text { Low growth and low income } \\
\text { region }\end{array}$ & $\begin{array}{c}\text { Quadrant II } \\
\text { High income but low growth region }\end{array}$ \\
\hline
\end{tabular}

Source: [7]

Where:

$\mathrm{R}_{\mathrm{ij}}$ : Economic growth in each district/municipal in Aceh Povince

$\mathrm{R}_{\mathrm{j}}$ : Average economic growth in Aceh Province

$Y_{\mathrm{ij}}$ : GRDP per capita in each district/municipal in Aceh Povince

$\mathrm{Y}_{\mathrm{j}}$ : Average GRDP per capita in Aceh Province

\section{Results And Discussion}

\subsection{Base Sector Region expansion Strategy Analysis in Aceh Province}

To acknowledge which sectors can be used as strategy in region expansion through base sector expansion in Aceh, we can carry out LQ (Location Quotient), in this analysis, it will show which sectors will become major sector out of nine analyzed sectors. For further description, it can be seen in Table 2 .

Table 2. LQ Calculation Result

\begin{tabular}{lrrrrrrrrr}
\hline Year & $\begin{array}{c}\text { Agricult } \\
\text { ure }\end{array}$ & $\begin{array}{c}\text { Mining } \\
\text { And } \\
\text { Quarryi } \\
\text { ng }\end{array}$ & $\begin{array}{c}\text { Manufa } \\
\text { cturing } \\
\text { Industry }\end{array}$ & $\begin{array}{c}\text { Electricity } \\
\text {. Gas and } \\
\text { Water } \\
\text { Supply }\end{array}$ & $\begin{array}{c}\text { Constru } \\
\text { ction }\end{array}$ & $\begin{array}{c}\text { Trade. } \\
\text { Hotel\& } \\
\text { Restaura } \\
\text { nt }\end{array}$ & $\begin{array}{c}\text { Transpo } \\
\text { rt\&Com } \\
\text { municati } \\
\text { on }\end{array}$ & $\begin{array}{c}\text { Finance. } \\
\text { Real } \\
\text { Estate and } \\
\text { Business } \\
\text { Services }\end{array}$ & Services \\
\hline 2002 & 16.917 & 16.404 & 0.6647 & 0.4247 & 0.7127 & 0.4373 & 19.641 & 10.634 & 0.7312 \\
2003 & 12.288 & 35.992 & 0.6118 & 0.1822 & 0.6252 & 0.7275 & 0.6776 & 0.1087 & 0.6244 \\
2004 & 10.517 & 25.145 & 45.805 & 0.1723 & 0.4889 & 0.5578 & 0.5244 & 0.0989 & 0.5884 \\
2005 & 14.511 & 24.708 & 0.6000 & 0.2564 & 0.5570 & 0.9314 & 10.107 & 0.1613 & 12.973 \\
2006 & 14.779 & 27.416 & 0.5139 & 0.2698 & 0.8368 & 0.8883 & 0.7688 & 0.1446 & 14.006 \\
2007 & 0.7633 & 10.819 & 23.861 & 0.5478 & 272.626 & 11.817 & 12.149 & 0.1912 & 0.7668 \\
2008 & 17.653 & 18.779 & 0.4540 & 0.3769 & 0.9929 & 0.9952 & 0.7976 & 0.1692 & 17.567 \\
2009 & 19.275 & 10.500 & 0.4501 & 0.4107 & 10.750 & 11.404 & 0.8024 & 0.1901 & 19.019 \\
2010 & 19.976 & 0.9611 & 0.4209 & 0.4883 & 11.484 & 11.342 & 0.7663 & 0.1930 & 19.042 \\
2011 & 21.105 & 0.9782 & 0.3973 & 0.4948 & 11.013 & 11.435 & 0.7703 & 0.1983 & 19.174 \\
2012 & 20.732 & 0.9453 & 0.3868 & 0.5063 & 11.309 & 11.571 & 0.7749 & 0.1999 & 19.376 \\
Total & 175.387 & 198.607 & 114.661 & 41.303 & 359.316 & 102.942 & 100.721 & 27.187 & 148.264 \\
Avar & $\mathbf{1 5 . 9 4 4}$ & $\mathbf{1 8 . 0 5 5}$ & $\mathbf{1 0 . 4 2 4}$ & $\mathbf{0 . 3 7 5 5}$ & $\mathbf{3 2 . 6 6 5}$ & $\mathbf{0 . 9 3 5 8}$ & $\mathbf{0 . 9 1 5 6}$ & $\mathbf{0 . 2 4 7 2}$ & $\mathbf{1 3 . 4 7 9}$ \\
age & & & & & & & & & \\
\hline \multicolumn{2}{c}{ Source:Data Processing Result (2017) } & & & & & &
\end{tabular}

Source:Data Processing Result (2017) 
In Table 3 the Klassen Typology result in 2003-2005 there was 1 (one) district/municipal in Aceh province which is the the category of high growth and high income region which was Banda Aceh. There was 1 (one) district/municipal in Aceh province which is in the category of high income but low growth region which was Lhokseumawe, then there were 10 (ten) regenciesin Aceh province which were the category of high growth but low income regions which were Aceh Utara, Aceh Timur, Aceh Barat, Aceh Tengah, Aceh Tenggara, Aceh Selatan, Aceh Singkil, Gayo Lues, Bener Meriah and Aceh Tamiang.

\subsection{Klassen Tipology Analysis}

The development of district/municipal region expansion in Aceh Province based on Klassen typology in 2003-2005 can be seen in the following Table 3.

Table 3. Klassen Typology Result in 2003-2005

\begin{tabular}{|c|c|c|c|}
\hline Y & $\mathbf{R}$ & $\mathbf{Y}_{\mathrm{ij}}<\mathbf{Y}_{\mathbf{j}}$ & $Y_{i j}>Y_{j}$ \\
\hline $\mathbf{R}_{\mathrm{ij}}>\mathbf{R}_{\mathbf{j}}$ & & $\begin{array}{l}\text { Quadrant III } \\
\text { High growth but low income region: } \\
\text { Aceh Utara, Aceh Timur, Aceh Barat, Aceh Tengah, } \\
\text { Aceh Tenggara, Aceh Selatan, Aceh Singkil, GayoLues, } \\
\text { Bener Meriah and Aceh Tamiang }\end{array}$ & $\begin{array}{l}\text { Quadrant I } \\
\text { High growth and high } \\
\text { income region: } \\
\text { Kota Banda Aceh }\end{array}$ \\
\hline $\mathbf{R}_{\mathrm{ij}}<\mathbf{R}_{\mathbf{j}}$ & & $\begin{array}{l}\text { Quadrant IV } \\
\text { Low growth and low income region: } \\
\text { Aceh Besar, Sabang, Pidie, Bireuen, Langsa, Aceh Barat } \\
\text { Daya, Nagan Raya, Aceh Jaya, Pidie Jaya, Subussalam } \\
\text { and Simeulue }\end{array}$ & $\begin{array}{l}\text { Quadrant II } \\
\text { High income but low } \\
\text { growth region: } \\
\text { Lhokseumawe }\end{array}$ \\
\hline
\end{tabular}

In Table 3 the Klassen Typology result in 2003-2005 there was 1 (one) district/municipal in Aceh province which is the the category of high growth and high income region which was Banda Aceh. There was 1 (one) district/municipal in Aceh province which is in the category of high income but low growth region which was Lhokseumawe, then there were 10 (ten) regenciesin Aceh province which were the category of high growth but low income regions which were Aceh Utara, Aceh Timur, Aceh Barat, Aceh Tengah, Aceh Tenggara, Aceh Selatan, Aceh Singkil, Gayo Lues, Bener Meriah and Aceh Tamiang.

Table 4. Klassen Typology Result in 2006-2008

\begin{tabular}{|c|c|c|}
\hline $\mathbf{Y}$ & $\mathbf{Y}_{\mathrm{ij}}<\mathbf{Y}_{\mathbf{j}}$ & $\mathbf{Y}_{\mathrm{ij}}>\mathbf{Y}_{\mathbf{j}}$ \\
\hline $\mathbf{R}_{\mathrm{ij}}>\mathbf{R}_{\mathbf{j}}$ & $\begin{array}{l}\text { Quadrant III } \\
\quad \text { High growth but low income region: } \\
\text { Aceh Besar, Sabang, Kota Banda Aceh, Pidie, } \\
\text { Bireun, Aceh Utara, Lhokseumawe, Aceh Barat Daya, } \\
\text { Aceh Barat, Aceh Tengah, Aceh Tenggara, Nagan Raya, } \\
\text { Aceh Jaya, Aceh Selatan, Aceh Singkil, GayoLues, } \\
\text { Subussalam, Simeulue and Bener Meriah }\end{array}$ & $\begin{array}{l}\text { Quadrant I } \\
\text { High growth and } \\
\text { high income region }\end{array}$ \\
\hline $\mathbf{R}_{\mathrm{ij}}<\mathbf{R}_{\mathbf{j}}$ & $\begin{array}{l}\text { Quadrant IV } \\
\quad \text { Low growth and low income region: } \\
\text { Aceh Timur, Langsa, Pidie Jaya and Aceh Tamiang }\end{array}$ & $\begin{array}{l}\text { Quadrant II } \\
\text { High income but low } \\
\text { growth region }\end{array}$ \\
\hline
\end{tabular}

Source:Data Processing Resut, 2017 
In Table 4 the Klassen Tipology result in 2006-2008 there were 19 (nineteen) districts/municipals in Aceh province which were in the category of high growth and high income regions, which were Aceh Besar, Sabang, Kota Banda Aceh, Pidie, Bireun, Aceh Utara, Lhokseumawe, Aceh Barat Daya, Aceh Barat, Aceh Tengah, Aceh Tenggara, Nagan Raya, Aceh Jaya, Aceh Selatan, Aceh Singkil, Gayo Lues, Subussalam, Simeulue and Bener Meriah. There were 4 districts/municipals in Aceh province which were in the category of low growth and low income regions which were Aceh Timur, Langsa, Pidie Jaya and Aceh Tamiang.

Table 5 Klassen Typology Result in 2009-2011

\begin{tabular}{|c|c|c|}
\hline $\mathbf{Y}$ & $\mathbf{Y i j}<\mathbf{Y j}$ & $\mathbf{Y} \mathbf{i j}>\mathbf{Y j}$ \\
\hline $\mathbf{R i j}>\mathbf{R j}$ & $\begin{array}{l}\text { Quadrant III } \\
\text { High growth but low income region: } \\
\text { Aceh Besar, Sabang, Kota Banda Aceh, Pidie, Bireun, } \\
\text { Aceh Utara, Lhokseumawe, Aceh Barat Daya, Aceh } \\
\text { Barat, Aceh Tengah, Aceh Tenggara, Nagan Raya, Aceh } \\
\text { Jaya, Aceh Selatan, Aceh Singkil, Gayo Lues, } \\
\text { Subulussalam, Simeulue and Bener Meriah }\end{array}$ & $\begin{array}{ll}\text { Quadrant I } & \\
\quad \text { High } & \text { growth } \\
\text { and high income } \\
\text { region }\end{array}$ \\
\hline $\mathbf{R i j}<\mathbf{R j}$ & $\begin{array}{l}\text { Quadrant IV } \\
\text { Low growth and low income region } \\
\text { Aceh Timur, Langsa, Pidie Jaya and Aceh Tamiang }\end{array}$ & $\begin{array}{l}\text { Quadrant II } \\
\text { High income but } \\
\text { low growth region }\end{array}$ \\
\hline
\end{tabular}

Source:Data Processing Resut, 2017

In Table 5 the Klassen Tipoloty result in 2009-2011, there were 13 (thirteen) regenciesin Aceh province which were in the category of high growth and high income regions which were Kota Banda Aceh, Pidie, Bireun, Aceh Barat Daya, Aceh Barat, Aceh Tengah, Aceh Tenggara, Nagan Raya, Aceh Jaya, Gayo Lues, Subussalam, Simeulue and Bener Meriah. There were 10 (ten) regenciesin Aceh province which were in the category of low growth and low income regions which were Aceh Besar, Sabang, Aceh Utara, Lhokseumawe, Aceh Timur, Langsa, Aceh Selatan, Pidie Jaya, Aceh Singkil and Aceh Tamiang.

There were 11 (eleven) regenciesin Aceh province which is the category of low growth and low income regions which were Aceh Besar, Sabang, Pidie, Bireuen, Langsa, Aceh Barat Daya, Nagan Raya, Aceh Jaya, Pidie Jaya, Subussalam and Simeulue.In Table 2 the Klassen Tipoloty result in 2006-2008 there were 19 (nineteen) regenciesin Aceh province which were in the category of high growth and high income regions, which were Aceh Besar, Sabang, Kota Banda Aceh, Pidie, Bireun, Aceh Utara, Lhokseumawe, Aceh Barat Daya, Aceh Barat, Aceh Tengah, Aceh Tenggara, Nagan Raya, Aceh Jaya, Aceh Selatan, Aceh Singkil, Gayo Lues, Subussalam, Simeulue and Bener MeriahThere were 4 regenciesin Aceh province which were in the category of low growth and low income regions which were Aceh Timur, Langsa, Pidie Jaya and Aceh Tamiang.

\section{Conclusion}

Region expansion strategy in Aceh province can be implemented in 5 working sectors which are agriculture, mining and quarrying, manufacturing industry, construction, and services sectors. Trade, hotel and restaurant and transportation and communication sectors are selfsupporting major sectors in Aceh. Electricity, Gas and Water Supply, and bank \& other 
financial institutions are not aceh province major sectors.In 2003-2005, there was 1 (one) district/manucipal in Aceh province which was categorized as high growth and high incomeregion. There was 1 (one) district/manucipal in Aceh province which was categorized as high income but low growth region.There were 10 (ten) regencies/manucipals in Aceh province which were categorized as high growth but low income regions and there were 11 (eleven) regencies/manucipals in Aceh province which were categorized as low growth and low income regions.In 2006-2008 there were 19 (nineteen) regencies/manucipals in Aceh province which were categorized as high growth and high income regions and 4 (four) regencies/manucipals in Aceh province which were categorized as low growth and low incomes. In 2006-2008 there were 13 (thirteen) regencies/manucipals in Aceh province which were categorized as high growth and high incomes and 10 (ten) regencies/manucipals in Aceh province which were categorized as low growth and low income regions.Based on the research result, it can be suggested that it is expected that from now on Aceh government can prioratize 5 (five) sectors for its region expansion strategy which are agriculture, mining and quarrying, manufacturing industry, construction and services

\section{References}

[1] Supriyati, Sumedi, and Saptana, "DINAMIKA KETENAGAKERJAAN DAN PENYERAPAN TENAGA KERJA DI PEDESAAN JAWA (Kasus di Propinsi Jawa Barat, Jawa Tengah dan Jawa Timur)," Pus. Penelit. dan Pengemb. Sos. Ekon. Pertan., vol. 10, no. 02, pp. 1-22, 2016.

[2] D. S. Gunawan and S. R. Gunawan, "Kabupaten Anggota Lembaga Regional Barlingmascakeb," vol. 9, no. April, pp. 26-43, 2008.

[3] BPS Aceh, Aceh Dalam Angka. Badan Pusat Statistik Aceh, 2012.

[4] Hariyanto dan Tukidi, "Konsep Pengembangan Wilayah dan Penataan Ruang Indonesia Di Era Otonomi Daerah,” vol. 4, no. 1, pp. 1-10, 2007.

[5] R. Ghalib, Ekonomi Regional. Bandung: Pustaka Ramadhan, 2005.

[6] Akil Syarifuddin, Konsep Pengembangan Wilayah di Indonesia. Jakarta: Dirjen Penataan Ruang Departemen Kimpraswil, 2002.

[7] R. Tarigan, Ekonomi Regional : Teori dan Aplikasi. Jakarta: Bumi Aksara, 2006.

[8] A. Y. Luntungan, "Analisis Investasi dan Pertumbuhan Ekonomi di Kota Bandung," J. Pembang. Ekon. dan Pembang. Drh., vol. 1, no. 2, 2008.

[9] B. Silalahi, "Analisis Pengaruh Variabel Kependudukan Terhadap Pdrb Harga Konstan Di Kabupaten Jepara (1986-2008),” 2011.

[10] D. Soebagiyo, "Kausalitas granger pdrb terhadap kesempatan kerja di provinsi dati i jawa tengah," J. Ekon. Pembang., vol. 8, no. 2, pp. 177-192, 2007. 